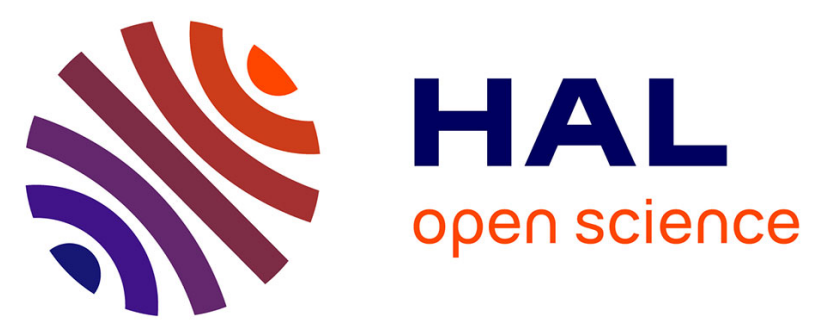

\title{
Effect of an exceptional rainfall event on the sea urchin (Paracentrotus lividus) stock and seagrass distribution in a Mediterranean coastal lagoon
}

Catherine Fernandez, Vanina Pasqualini, Charles-François Boudouresque, Monique Johnson, Lila Ferrat, Angela Caltagirone, David Mouillot

\section{To cite this version:}

Catherine Fernandez, Vanina Pasqualini, Charles-François Boudouresque, Monique Johnson, Lila Ferrat, et al.. Effect of an exceptional rainfall event on the sea urchin (Paracentrotus lividus) stock and seagrass distribution in a Mediterranean coastal lagoon. Estuarine, Coastal and Shelf Science, 2006, 68 (1-2), pp.259-270. 10.1016/j.ecss.2006.02.020 . hal-01769224

\section{HAL Id: hal-01769224 \\ https://hal.science/hal-01769224}

Submitted on 17 Apr 2018

HAL is a multi-disciplinary open access archive for the deposit and dissemination of scientific research documents, whether they are published or not. The documents may come from teaching and research institutions in France or abroad, or from public or private research centers.
L'archive ouverte pluridisciplinaire HAL, est destinée au dépôt et à la diffusion de documents scientifiques de niveau recherche, publiés ou non, émanant des établissements d'enseignement et de recherche français ou étrangers, des laboratoires publics ou privés. 


\title{
Effect of an exceptional rainfall event on the sea urchin (Paracentrotus lividus) stock and seagrass distribution in a Mediterranean coastal lagoon
}

\author{
Catherine Fernandez ${ }^{a, *}$, Vanina Pasqualini ${ }^{b}$, Charles-François Boudouresque ${ }^{c}$, \\ Monique Johnson ${ }^{\mathrm{d}}$, Lila Ferrat ${ }^{\mathrm{b}}$, Angela Caltagirone ${ }^{\mathrm{c}}$, David Mouillot ${ }^{\mathrm{e}}$

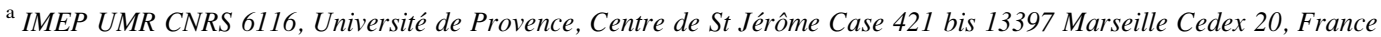 \\ b IE UMR CNRS 6134, Université de Corse, Faculté de Sciences et Techniques, B.P. 52, 20250 Corte, France \\ ${ }^{\mathrm{c}}$ DIMAR UMR CNRS 6540, Centre d'Océanologie de Marseille, Case 901 Av. de Luminy, 13288 Marseille Cedex 9, France \\ ${ }^{\mathrm{d}}$ GBPC UMR CNRS 6556, Université de Poitiers, 40 avenue du Recteur Pineau, 86022 Poitiers Cedex, France \\ e UMR CNRS-UMII 5119, Ecosystèmes Lagunaires, Université Montpellier II cc 93, 34095 Montpellier Cedex, France
}

\begin{abstract}
A shallow Mediterranean brackish lagoon (Urbinu, Corsica), 700 ha in surface area, characterized by low freshwater input and permanent communication with the open sea, and therefore by relatively stable salinity (usually 30-38), was subject in late 1993 to an exceptional rainfall event occurring on an average once every 50 years: $450 \mathrm{~mm}$ in $48 \mathrm{~h}$ (compared to the average annual precipitation of $650 \mathrm{~mm}$ ). The volume of freshwater that poured into the lagoon corresponds to $36 \%$ of its volume. As a result, salinity dramatically dropped while turbidity increased. The seagrass Cymodocea nodosa and other habitats were mapped before (1990) and after $(1994,1996,1999)$ the rainfall event, and the sea urchin Paracentrotus lividus stock was estimated together with its population structure. In 1994, after the rainfall event, the surface area of seagrass meadows moderately declined, but it cannot be ruled out that this loss may be within their usual inter-annual fluctuations. The sea urchin stock dropped by $50 \%$ (6-3 million individuals). Low salinity, turbidity and siltation were probably the reasons for the changes in sea urchin population in addition to variability of dynamic population parameters (e.g. recruitment, mortality). The recovery of sea urchin stock was completed within a few years (six years or less). The high population dynamics and the high recruitment potential of sea urchins may act as a mechanism to maintain sea urchin populations in this highly variable habitat. These results reflect the resilience and high adjustment stability of the system.
\end{abstract}

Keywords: bootstrapping; stock assessment; echinoderms; mortality; seagrass; cartography; Mediterranean; France

\section{Introduction}

Coastal lagoons are of primordial importance. In the light of their great productivity, coastal lagoons have long been exploited by man, be it through fishing activities or extensive or semi-intensive aquaculture (fish and/or shellfish; Kjerfve, 1994; Solidoro et al., 2003), and are thus of great economic value. From an ecological point of view, coastal lagoons, like

\footnotetext{
* Corresponding author.
}

estuaries and coastal wetlands, can be defined as Critical Transition Zones (CTZ), given their position between terrestrial, freshwater and marine interfaces (Levin et al., 2001). As such, these zones are able to provide essential ecosystem services such as shoreline protection, water quality improvement, habitat and food for migratory and resident animals and recreational areas for human populations (Levin et al., 2001).

Coastal lagoons are considered to be particularly vulnerable environments to climatic or hydrological fluctuations. This is the consequence of low inertia to external events due to shallowness of water masses coupled with an interface position between marine and watershed water bodies leading to 
continuous perturbations such as tidal variations, winds, storms and chaotic freshwater discharges which may be daily, seasonal or annual, often leading to environmental crises (Kjerfve, 1994). As a consequence, benthic macrofaunal populations living in lagoons are exposed to intensive environmental pressures, potentially leading to mortality. It is feared that these pressures will become more frequent as a result of ongoing changes, such as climate warming and anarchic land use.

Coastal lagoons harbour a variety of species that differ substantially in their tolerance to hydrological fluctuations: opportunistic species with high ecological tolerance (often living in highly eutrophicated environments), euryhaline species typical of brackish waters but also more or less stenohaline marine species (Lardicci et al., 1997). In coastal lagoons, the latter species are mainly present when inlets, connecting lagoons to the open sea, are large enough to allow inflow of seawater and thus higher salinity levels. This is the case for echinoderms and sea urchins in particular. Where they occur, sea urchin populations play a key role in the functioning of benthic communities, for instance by controlling distribution, biomass and production of macrophytes (Lawrence and Sammarco, 1982) and can exert a significant influence on habitat structure, even in communities with low sea urchin density (Palacin et al., 1998). In seagrass ecosystems, sea urchin grazing can be substantial (Heck and Valentine, 1995) and can create an area of low seagrass biomass or even eliminate seagrasses by overgrazing (Bak and Nojima, 1980; Maciá and Lirman, 1999). In Mediterranean coastal ecosystems, Paracentrotus lividus (Lamarck) is known to cause overexploitation of seagrasses (Verlaque, 1987) particularly in Posidonia oceanica (Lineaus) Delile beds. Even though Cymodocea nodosa is clearly preferred to $P$. oceanica by this sea urchin (Traer, 1980; Cebrian and Duarte, 1998), there have been few studies on the impact of grazing on the former seagrass. Nevertheless, Cebrian et al. (1996) underline the trophic importance of $C$. nodosa as a food resource for herbivores. The consumption of $C$. nodosa by grazing could reach $45 \%$, and the role of herbivores in controlling seagrass production increases notably from exposed to sheltered meadows (Cebrian et al., 1996). In coastal lagoons, where $C$. nodosa beds are particularly extensive (Pasqualini et al., 2006), surprisingly little is known about sea urchin populations living in these environments (Fernandez and Boudouresque, 1997; Fernandez et al., 2001) whereas they are the main consumers of $C$. nodosa beds. This sea urchin is assumed to consume, when density is around $0.5 \mathrm{ind} / \mathrm{m}^{2}$, about $1-7 \%$ of the $C$. nodosa production (Fernandez, unpublished data); for density around $10-30 \mathrm{ind} / \mathrm{m}^{2}$ (which has already been observed in coastal lagoons: Fernandez and Caltagirone, 1990), consumption reaches $100 \%$ of the $C$. nodosa production and induces overgrazing. As a consequence, studies about sea urchin population stocks and structure are of fundamental importance in terms of our understanding of shallow subtidal ecosystems.

The aim of the present study is to seize the opportunity of an exceptional rainfall event which occurs on an average once in 50 years to measure its impact on a coastal lagoon together with the time necessary for the system to recover. Two proxies were used, namely, the surface area covered by main benthic habitats and population density of the sea urchin Paracentrotus lividus, a stenohaline species prone to be sensitive to a drop in salinity. The particular questions addressed are how these habitats and populations react to drastic variations in the hydrological conditions, and whether they are resilient enough to recover following such an exceptional rainfall event, particularly since such events may become more frequent in the context of global climate change.

\section{Materials and methods}

\subsection{Sampling site characteristics}

This study was carried out in a coastal zone in Corsica, France (Fig. 1). This island presents a Mediterranean climate, characterized by a complex pattern of spatial and seasonal variability, with wide and unpredictable fluctuations in rainfall from one year to the next. Extreme rainfall events of high intensity are becoming an increasingly frequent phenomenon in this region as a result of the ongoing climatic changes affecting the Mediterranean region (Christensen and Christensen, 2004), which disrupt both natural and human systems (IPCC, 1995). Between October 31 and November 1, 1993, exceptional rainfall followed by flooding occurred in Corsica. The rainfall in the lagoon and watershed area was around $450 \mathrm{~mm}$ in $48 \mathrm{~h}$ (compared to an average annual precipitation of $650 \mathrm{~mm}$; Fig. 2). Such high rainfall levels occur about once every 50 years (Météo France data). The coastal lagoon of Urbinu is situated on the East coast of Corsica $\left(42^{\circ} 03^{\prime} \mathrm{N} ; 9^{\circ} 28^{\prime}\right.$ E; Fig. 1). Its shape is sub-circular with a diameter varying from 2.8 to $3.0 \mathrm{~km}$. The lagoon is $5 \mathrm{~m}$ deep on an average (less than $10 \mathrm{~m}$ maximum), and has a small watershed region $\left(31 \mathrm{~km}^{2}\right)$. This lagoon presents limited terrestrial inputs and the inlet is dredged to maintain suitable conditions for fishing and fish-farming. This lagoon is characterized by the homogeneity of its water mass (except the river mouth and the connexion to the sea) without any stratification. The volume of freshwater discharge into the lagoon was about $14 \times 10^{6} \mathrm{~m}^{3}$ during the exceptional rainfall. This amount corresponds to roughly $36 \%$ of the total volume of water within the lagoon.

\subsection{Environmental data}

The lagoon of Urbinu is a rather homogeneous water body, both horizontally and vertically. When stratification occurs (temperature and salinity), change with depth only concerns the deeper part, where the studied species are absent. The time series (1990-1999) of environmental water parameters were measured in the subsurface $(0.5-1 \mathrm{~m}$ depth) of the central (i.e. deepest: $8-9 \mathrm{~m}$ ) part of the lagoon. Temperature and oxygen were measured daily in the morning (Y. Leberigaux and L. Bronzini, unpublished data) using an Oxyguard Handy MK II oxygen-temperature meter. Turbidity and salinity were generally measured weekly or bimonthly in the morning (IFREMER and University of Corsica data) using a WTW LF 197 (Wissenschaftlich Technische Werkstätten) conductimeter 


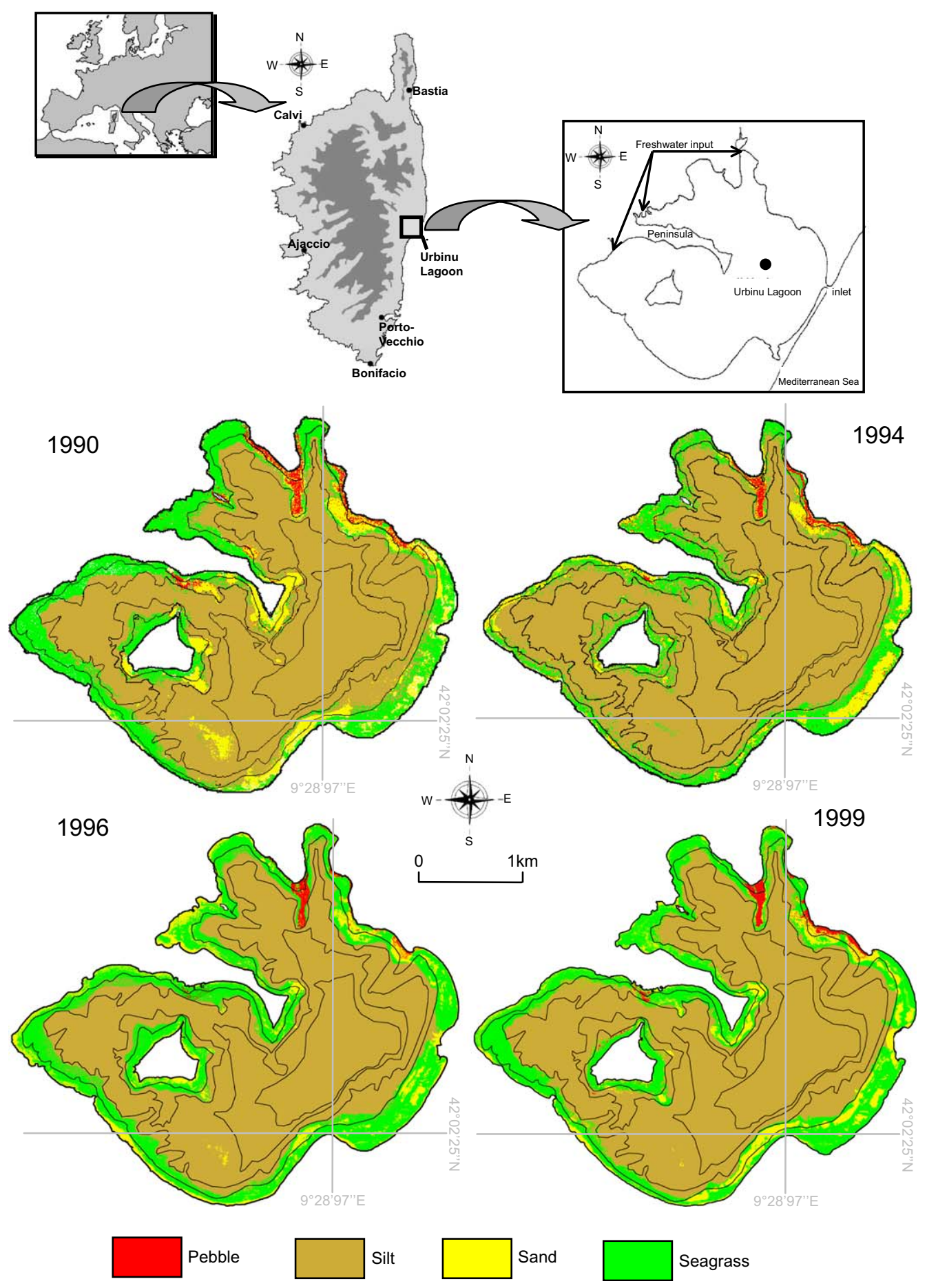

Fig. 1. Distribution of benthic communities and bottom types in the Urbinu lagoon (Corsica, Mediterranean) in 1990, 1994, 1996 and 1999. Depth contours: 2, 5, 8 and $9 \mathrm{~m}$ depth. Characteristics of Urbinu lagoon: localization of inlet, connecting lagoons to the open sea, and freshwater inputs are also shown. - In the central part of the lagoon represents the location where oxygen, temperature and salinity data were recorded.

and an HACH 2100A turbidimeter. IFREMER data are available at http://www.ifremer.fr/envlit/region/reg11corse/ index.htm\#.

\subsection{Cartography and surface area estimations}

Preliminary samplings allowed us to identify five habitats: (1) clear sand bottom, (2) pebble bottom and coarse shell, (3) seagrass meadows (Cymodocea nodosa), (4) silt bottom between -2 and $-8 \mathrm{~m}$ and (5) silt bottom at more than $8 \mathrm{~m}$ depth (hereafter sand, pebbles, seagrass, silt and deep silt, respectively). Paracentrotus lividus occurs only in the first four habitats.

To map the habitats, computer image processing based on aerial photographs was used. This technique combines a high level of precision and rapid processing (Pasqualini 


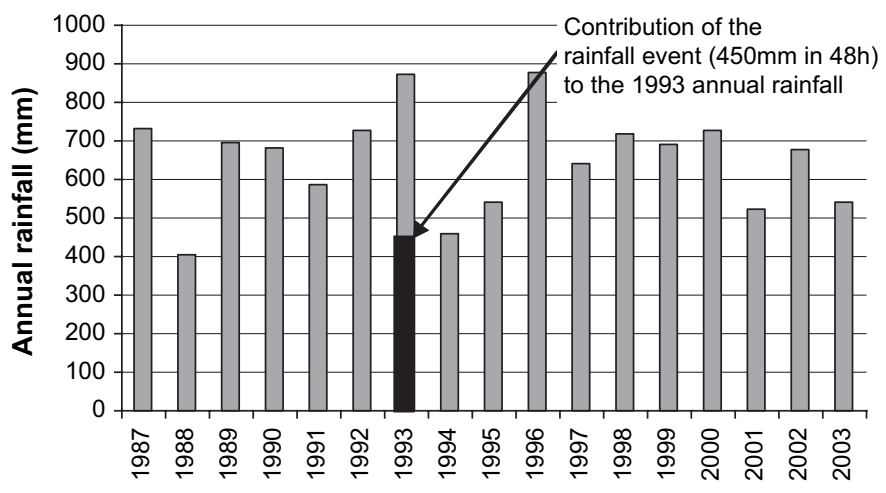

Fig. 2. Annual variations of rainfall (in mm) from 1987 to 2003 in Urbinu lagoon (Corsica, Mediterranean). The black rectangle represents the contribution of the rainfall event to the annual rainfall in 1993 (Météo France data).

et al., 1997). Color photographs used for the cartography (three in 1990, one in 1994, one in 1996 and one in 1999) were from May to June, those dates corresponding to periods when seagrass vegetation was the most developed. The turbidity of the lagoon prevented us from distinguishing habitats below depth of $5 \mathrm{~m}$. However, observations by scuba diving revealed that areas deeper than $5 \mathrm{~m}$ were silt bottoms. In the present study, the image processing consisted of optimizing the visualization of seagrass meadows, and pebble, sand and silt bottoms. The method employed for the digitized photograph analysis, using MULTISCOPE software (version 2.4, Matra Cap System and Information ${ }^{\circledR}$ ), was the same as that used by Pasqualini et al. (1997). Digitization of aerial photographs was carried out using a color scanner, using IMAGEIN SCAN and PAINT software (Image In $^{\circledR}$ ), in 16.8 million colors. The resolution was adjusted to obtain a pixel of $2 \mathrm{~m}$. Geometric rectification using identified reference points was performed by comparing the working image and the IGN reference map, scale 1/25000 (TOP 25, $\mathrm{N}^{\circ} 4352$ OT). The image was processed to optimize information using specific techniques (filters, ACP, color composition). Reference polygons identified in situ allowed us to extend the processing to the entire image (Pasqualini et al., 1997). Observations were made by either pinpoint dives or using the transect method. Localization of test parcels was done from identified landmarks. Once the map was completed, field observations were used to validate the map. The surface area occupied by each habitat was then calculated and mapped. The accuracy of the maps was determined using a scale of reliability (Pasqualini et al., 1997). Factors intrinsic to the technique used and to the site studied may affect the quality of the results obtained. The identification and assessment of the impact of these various parameters provides the basis for a scale of reliability.

\subsection{Sea urchin populations}

Population densities of the sea urchin Paracentrotus lividus were measured in June 1990, 1994, 1996 and 1999 using a stratified sampling protocol with optimum allocation
(Frontier, 1983). Populations are usually influenced by spatial and temporal effects. Thus, a simple random sampling procedure would lead to very high variability in density estimates and thus to a lack of power for statistical tests. In order to reduce this variability we used a stratified sampling design based on strata (spatial or temporal) where samples are assumed to be more homogeneous and can be considered as replicates. The number of quadrats used for each spatial stratum reflects its relative importance within the lagoon (Frontier, 1983).

Paracentrotus lividus population density depends, among other factors, on the habitat (Maggiore et al., 1987). In Urbinu lagoon, sea urchins occur, in variable densities, in four habitats: pebble bottoms (recruitment area), seagrass beds (growth area) but also in silt and sandy habitats. These last two habitats seem to be principally traversed during migrations which take place between the recruitment and growth areas (Fernandez et al., 2001).

Sea urchin population counts for each habitat were carried out using random sampling. A $1-\mathrm{m}^{2}$ quadrat was selected as a sampling unit. The number of quadrats varied (Table 1) as a function of habitat and sampling year in order to take into account sea urchin variability induced by these two factors. For counts within the seagrass meadow, rhizomes were closely examined and in the pebble habitat each pebble was turned. Individuals measuring less than $8 \mathrm{~mm}$ (diameter without the spines) were not included in our study. Sea urchins occurring within the quadrats were measured in 1990, 1994 and 1999, using a calliper rule with a precision of $1 \mathrm{~mm}$ (ambitus diameter without the spines). Moreover, dives were regularly carried out from June 1990 to September 1993 (monthly from May 1991 to July 1992; Fernandez and Boudouresque, 1997; more occasionally from September 1992 to September 1993) on pebble areas located in the Northern part of the lagoon and on seagrass areas located in the Eastern part of the lagoon. Several densities were measured on an occasional basis during these dives $\left(n=5-9 \mathrm{~m}^{2}\right)$.

\subsection{Data analysis}

\subsubsection{Confidence limits for sea urchin density estimations}

Estimating the abundance of organisms generates several methodological problems (Turon et al., 1995b). A particular

Table 1

Number of $\mathrm{m}^{2}$ explored and number of sea urchin measured in the four habitats of Urbinu lagoon during the study period ( - data not available)

\begin{tabular}{lrrrr}
\hline & 1990 & 1994 & 1996 & 1999 \\
\hline Quadrat number & & & & \\
Pebble & 56 & 60 & 60 & 31 \\
Silt & 183 & 87 & 87 & 247 \\
Sand & 61 & 67 & 67 & 322 \\
Seagrass & 84 & 178 & 178 & 220 \\
Urchin number & & & & \\
Pebble & 286 & 166 & - & 243 \\
Silt & 52 & 39 & - & 59 \\
Sand & 67 & 63 & - & 69 \\
Seagrass & 151 & 78 & - & \\
\hline
\end{tabular}


problem is the establishment of confidence limits when data do not exhibit a normal distribution pattern. A comparison of methods in the estimation of sea urchin density reveals that the bootstrap method is the best tool for setting confidence intervals on density estimates (Turon et al., 1995b). Accordingly, in the present study, the percentile method described by Efron (1979) was used to estimate the sea urchin density confidence limits for each habitat and year. Details on this method can be found in Efron and Tibshinari (1993) or in Manly (1998). In the bootstrap methodology, subsamples are obtained by resampling the original data set with replacements to generate the bootstrap distribution of the parameter of interest, i.e. the mean sea urchin density. The $100(1-\alpha) \%$ confidence interval for the true value of the parameter is then given by the two values that encompass the central interval $100(1-\alpha) \%$ of this distribution. Using this distribution, we are able to obtain the unbiased mean of sea urchin density (Efron and Tibshinari, 1993). This procedure is implemented using S-plus software; 10000 simulation runs or resamples were computed (Legendre and Legendre, 1998).

Density comparison among habitats or between years was performed using the Kruskall-Wallis and StudentNewman-Keuls non-parametric tests (as variance homogeneity could not be obtained by transformation; Zar, 1999). These analyses were performed using the technical support of Statgraphics $^{\circledR}$ package (v.2.1).

\subsubsection{Total stock estimations in the lagoon}

A Monte Carlo method (Manly, 1998) was used to estimate total sea urchin stock within the lagoon. Using this randomisation procedure, we were able to generate the distribution pattern of sea urchin densities and total stock estimations within the lagoon.

- The first step consists in randomly choosing the habitat to be sampled, the probability that a given habitat is sampled being proportional to its surface.

- The second step consists in randomly choosing, from the set of observed data for the adequate habitat, the data to be included in the Monte Carlo subsample.

For each year this procedure was repeated 10000 times as suggested by Legendre and Legendre (1998). The subsample size for each year was the same as the observed samples. With these distributions, we can determine the confidence limits (Manly, 1998). We implemented the Monte Carlo method in a $\mathrm{C}++$ program, and the Knuth (1997) procedure was used to generate random numbers.

\subsubsection{Population structure}

A size class interval of $0.3 \mathrm{~cm}$, already used for this species, was chosen (Fenaux et al., 1987). Variations in the demographic structure, as a function of sampling year for each habitat, or as a function of habitat for each sampling year, were analysed using the Chi squared test (Zar, 1999).

Different cohorts were identified using the Bhattacharya (1967) method. Bhattacharya's method is a modal progression analysis technique that does not require an estimate of the number of components included in the observed distribution (Bhattacharya, 1967). These analyses were performed using FISAT II v.1.0 package (FAO - ICLARM software).

Finally, total biomass was estimated using size structure and density data. The mean weight is deduced from the mean size and the allometric relationships established from a sample of 500 representative individuals of the population: $W=0.0027 D^{2.4703}(W$ : wet weight in $\mathrm{g}$ and $D$ : test diameter in $\mathrm{mm}$ ).

\section{Results}

\subsection{Environmental data}

Environmental data were obtained using physical-chemical water parameters during part of or all of the study period (Fig. 3). For the water temperature, the highest values were observed in July and August (approximately $30{ }^{\circ} \mathrm{C}$, maximum July 1995: $31.7{ }^{\circ} \mathrm{C}$ ), whereas the lowest values were recorded in January-February (approximately $8{ }^{\circ} \mathrm{C}$, minimum January 1993: $6.1^{\circ} \mathrm{C}$ ). No temperature anomalies were recorded throughout the period of study, including after the freshwater runoff event. Furthermore, temperature did not differ substantially from one year to the next for any given season. For oxygen levels, data only concerned the 1995-1996 period. According to Lebérigaud (personal communication) and IFREMER (unpublished data), oxygen levels during these two years follow the general pattern in this lagoon, with drops in oxygenation during summer that are linked, in particular, to high water temperature. In addition, people working in the lagoon (fishermen, fish farmers) throughout the study period (1990-1999) did not notice any exceptional drops in oxygen levels particularly after the runoff. The salinity values generally fluctuated throughout the year between 30 and 38 PSU (Fig. 3). The lowest salinity value (23 PSU), on November 8, 1993, can be attributed to the exceptional rainfall followed by flooding that occurred in Corsica on October 31 and November 1, 1993. The salinity measured on November 8, 1993, one week after the rainfall event, was the lowest recorded at the site between 1987 and 2002 (data obtained from IFREMER). More specifically, during the days following the rainfall, the salinity drop was up to 7 PSU, for a period of over three days, in both pebble and seagrass habitats (Fernandez, pers. obs.). Turbidity values were generally between 0 and 4 NTU. The highest value recorded (6.5 NTU) was observed on November 8, 1993. Such a high value may be due to either the wind (sediment re-suspension) or the water runoff from the watershed that spilled into the lagoon. As far as the 1993 rainfall event is concerned, meteorological data support the latter hypothesis. In addition, the NTU peak was the only one observed throughout the study period, coupled with low salinity values.

\subsection{Cartography and surface area estimations}

The total surface area of the lagoon is about 700 ha, excluding swampy zones, and sea urchin occurs over about 550 ha 

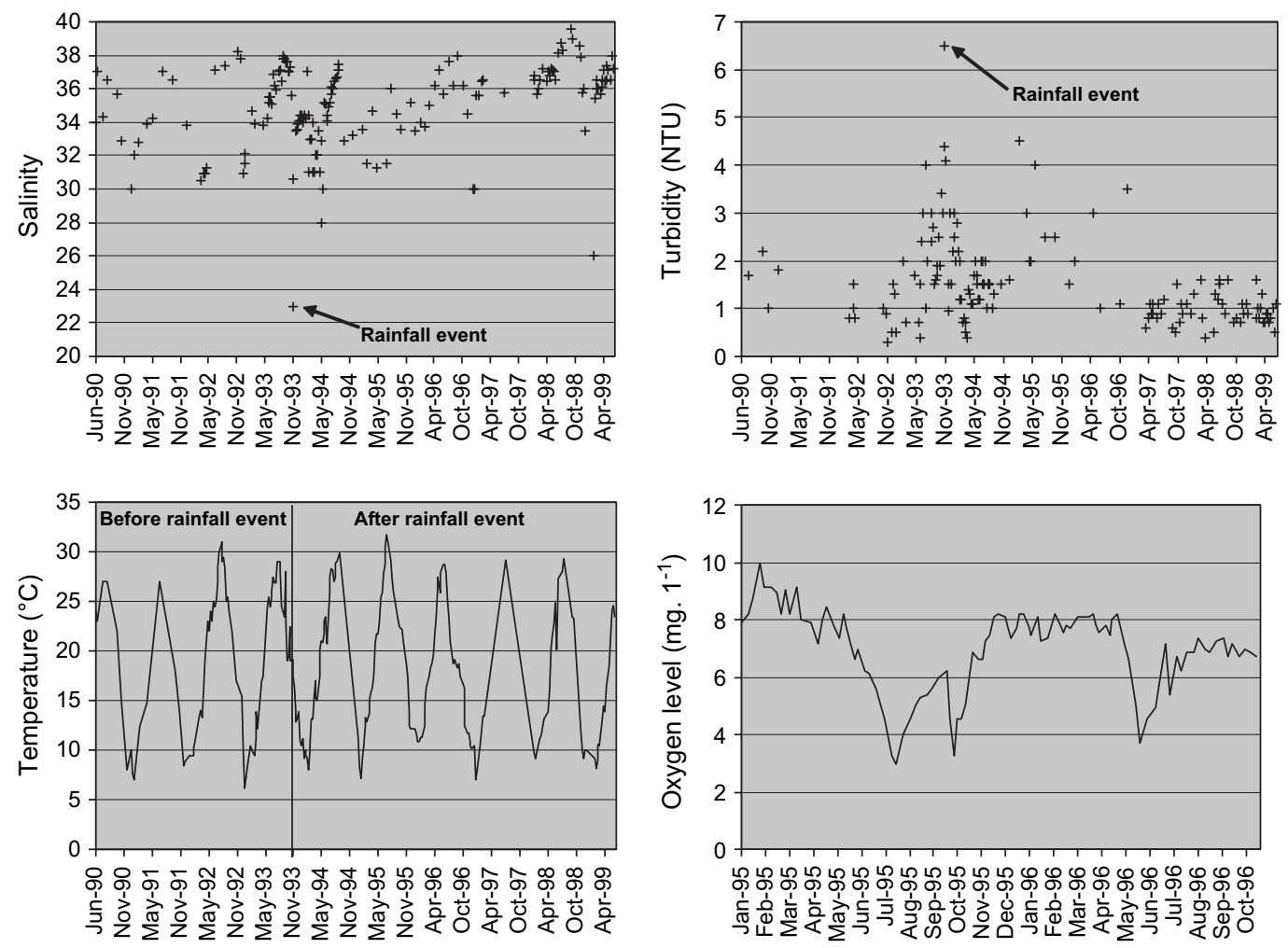

Fig. 3. Environmental data observed in Urbinu lagoon (Corsica, Mediterranean) during the study period.

(depth $<8 \mathrm{~m}$ ). Sand is mainly found on the periphery of the lagoon. Pebbles are limited to very small surfaces, mainly located in the Northern part of the lagoon. Silt and deep silt are the main habitats of the lagoon, occupying almost the entire central region. Seagrass meadows form a discontinuous belt along the edge of the lagoon that can reach up to $300 \mathrm{~m}$ width. These meadows generally occur in shallow areas (down to $4 \mathrm{~m}$ depth) (Fig. 1). Seagrass meadows are mostly made up of Cymodocea nodosa with few shoots of Nanozostera noltii (Hornem.) Tomlinson and Ruppia cirrhosa (Petagna) Grande may occur locally. Analysis of the results, based on the scale proposed by Pasqualini et al. (1997), gave reliability values for the surface area of all habitat estimates of $79 \%$ for 1990 and 82\% for 1994, 1996 and 1999.

The most conspicuous event during the study period was a significant moderate regression of the sand and seagrass habitats and an increase in the silt surface areas recorded in June 1994 (in comparison with 1990; Fig. 4; Chi squared test, $p<0.001)$. This decline was steeper in deep $(2-5 \mathrm{~m})$ than in shallow $(0-2 \mathrm{~m})$ waters $(43 \%$ vs $12 \%$, respectively, 1990-1994). In 1996, a strong increase in the surface area covered by seagrasses (Chi squared test, $p<0.001$ ) at the expense of silt but also sand and pebble habitats was observed. Finally, no conspicuous differences in relative surface areas were observed although the localization of the seagrass meadows was altered between 1990 and 1999 (Chi squared test, $p>0.05)$. In 1999 the meadows exhibited a greater extension at the peninsula with a concomitant regression in the northern and western parts of the lagoon (Chi squared test $p$-values).

\subsection{Confidence limits for sea urchin density and total stock estimates in the lagoon}

The bootstrap procedure provides robust estimates for sea urchin density in each habitat (Fig. 5). Statistical analysis revealed that, for the four sampling years, densities varied significantly among the four habitats (Kruskall-Wallis tests, 204.1 $<W<266.2, p<0.001)$. The multiple comparisons

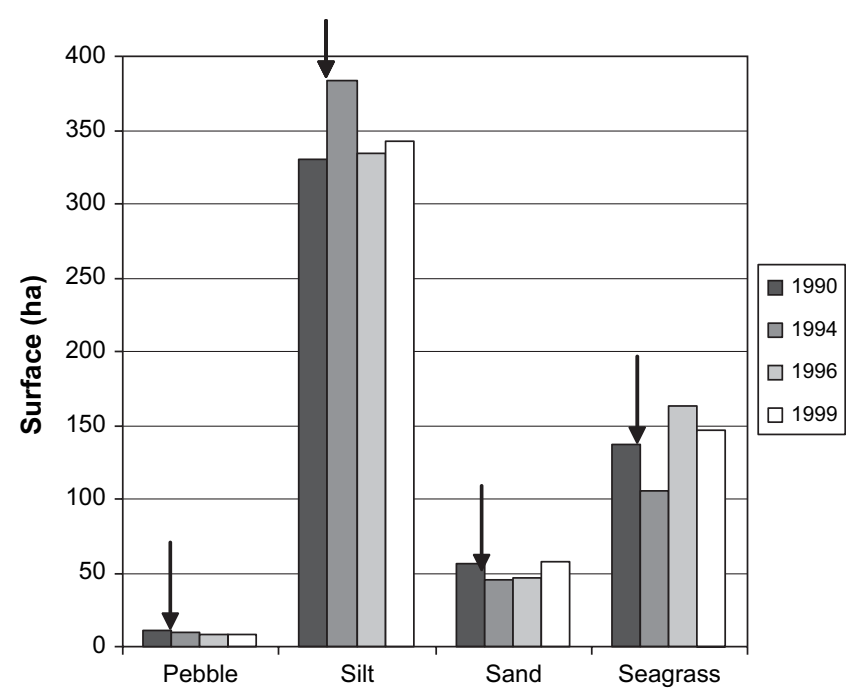

Fig. 4. Surface area (ha) occupied by each habitat in Urbinu lagoon (Corsica, Mediterranean) in 1990 and 1999, between 0 and $8 \mathrm{~m}$ in depth. The arrow separates the data obtained before and after the rainfall event. 

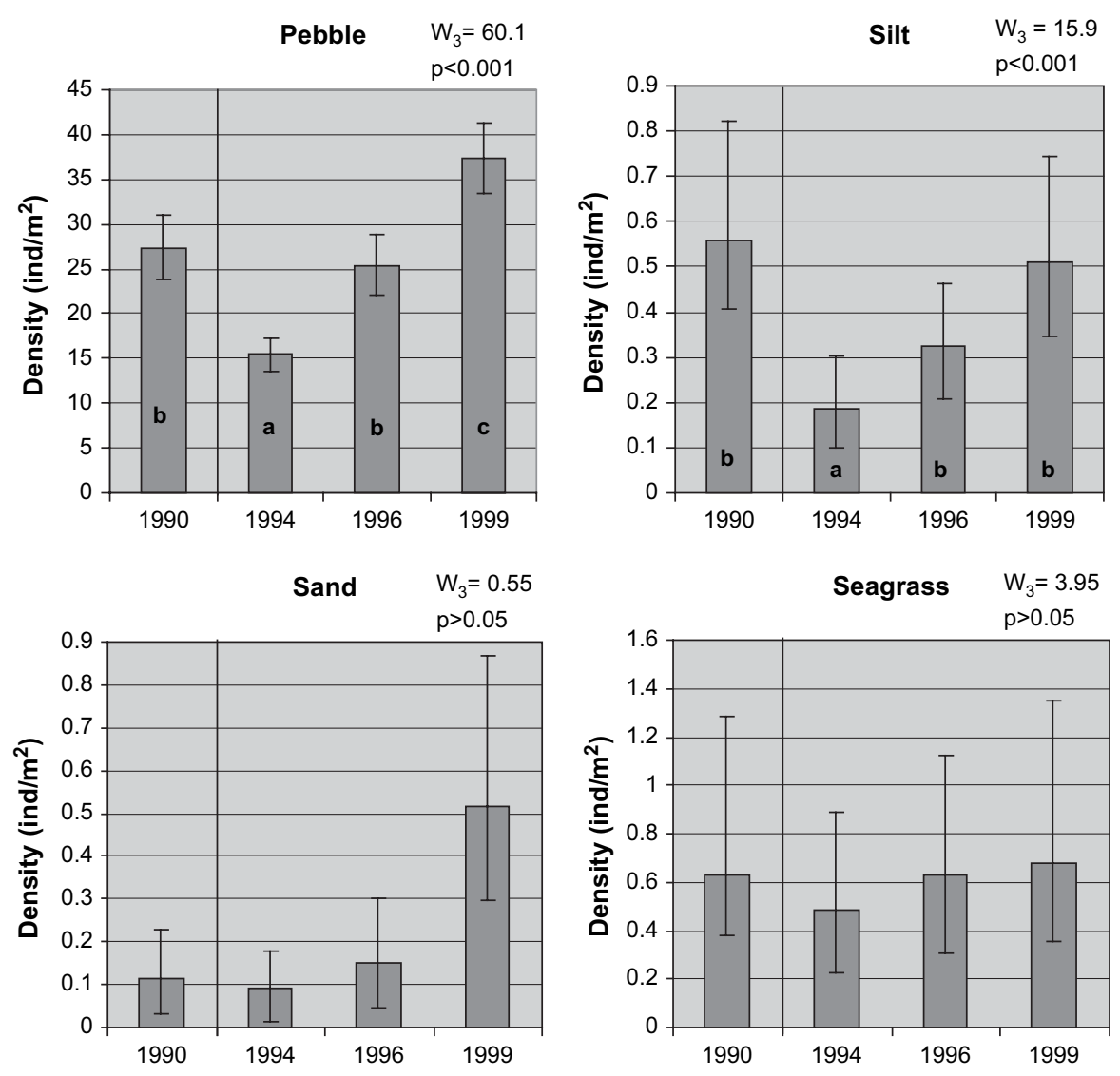

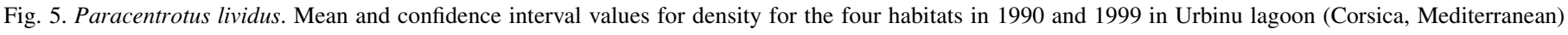

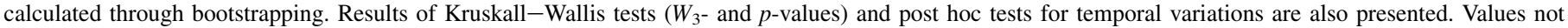
differing at $5 \%$ are denoted with the same letter. The line separates the data obtained before and after the rainfall event.

test revealed that pebbles supported high urchin densities while the other habitats exhibited lower densities (SNK tests, $p<0.05)$. The pebble habitat, despite its small surface area (approximately $10 \mathrm{ha}$ ), contained more than half of the lagoon's sea urchin population for all four sampling years.

Comparison between the sampling years revealed that mean population density significantly decreased between 1990 and 1994 (Fig. 5). The number of sea urchin was $44 \%$ and 66\% lower than its initial value in pebble and silt habitats, respectively (Kruskall-Wallis tests, $W_{3}=60.1$ and 15.9 , respectively, $p<0.001$; SNK tests, $p<0.001$ ). After 1994, urchin population density increased to either return to initial values (1996 for the silt habitat, SNK test, $p<0.05$ ) or exceed initial values (1999 for the pebble habitat, SNK test, $p<0.05$ ). Population density within the two remaining habitats (sand and seagrass) did not vary significantly throughout the study period (Kruskall-Wallis tests, $W_{3}=0.55$ and 3.95, respectively, $p>0.05)$.

The Monte Carlo method makes it possible to estimate the total number of sea urchins present within the lagoon for any given year during the study period (Fig. 6). These results reveal a drop in sea urchin numbers between 1990 and 1994,

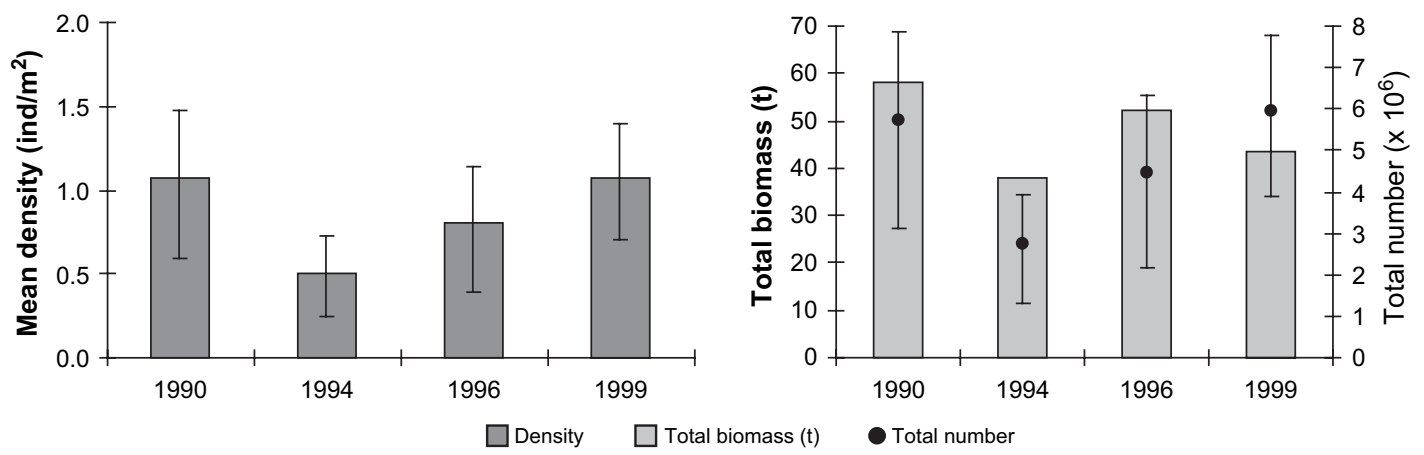

Fig. 6. Paracentrotus lividus. Densities, total number $\left(\times 10^{6}\right)$ calculated through Monte Carlo method ( \pm confidence interval) and total biomass in all the Urbinu lagoon areas $<8 \mathrm{~m}$ depth (Corsica, Mediterranean). 
representing a total decrease of 54\% (Fig. 6). Total sea urchin number dropped from approximately 6 million to approximately 3 million individuals. Sea urchin number increased from 1996 onward (4.5 million individuals) to reach 6 million individuals in 1999, a stock level equivalent to that observed in 1990 (Fig. 6). The decrease in biomass is less drastic marked with a drop from 58 tons in 1990 to 38 tons in 1994 representing a reduction of $35 \%$ (Fig. 6).

Finally, observations obtained during some occasional dives on pebble and seagrass areas between 1991 and 1993 show that mean sea urchin density remained at $23.40,31.40$ and $22.80 \mathrm{ind} / \mathrm{m}^{2}$ in pebble and $0.50,0.75$ and $055 \mathrm{ind} / \mathrm{m}^{2}$ in seagrasses, respectively in 1991, 1992 and 1993. Moreover, visual observation shows that, in pebble habitat, young sea urchins $(<2 \mathrm{~cm})$ were always present during this period.

\subsection{Population structure}

Population structure varied significantly among habitats (Fig. 7, Chi squared tests, $p<0.001$ ). All cohort sizes, calculated using the Bhattacharya method, do not occur in all habitats and the number of individuals in each cohort differs between habitats. The smaller individuals were present in the pebble habitat whereas the larger individuals were mostly observed within the seagrass meadows. Population structure also varied as a function of the sampling year. Two major changes can be noted:

(1) A decrease in the number of small individuals in the pebble habitat in 1994 (Chi squared test, $\chi^{2}=900.0, \mathrm{df}=22$, $p<0.001$ ). Most of individuals present in 1990 belong to cohort 1 (mean cohort size $19.2 \mathrm{~mm}$ ), whereas the majority of individuals present in 1994 belongs to cohort 2 (mean cohort size $28.3 \mathrm{~mm}$ ). Similarly, the smallest cohort was not observed in the silt habitat in 1994 despite the fact that this cohort was present in 1990 and 1999.

(2) The presence of a small cohort occurring only in 1999 in both seagrass and sandy habitats (Chi squared test, $\left.\chi^{2}=102.7, \mathrm{df}=26, p<0.001\right)$.

The density of small individuals $(<20 \mathrm{~mm})$ on pebble bottoms greatly varied during the study period with $18 \mathrm{ind} / \mathrm{m}^{2}$ in 1990, 1 in 1994 and 31 in 1999 whereas adult populations $(>20 \mathrm{~mm})$ remained more constant $\left(6-10 \mathrm{ind} / \mathrm{m}^{2}\right)$.

\section{Discussion}

The results obtained over the 10 years spanned by this study confirm the great variability in environmental parameters that can be experienced by this kind of coastal ecosystem. The rainfall event of late 1993 was the heaviest since 1958. Such events occur about once every 50 years. It was associated, over the study period, with the highest peak of turbidity and the lowest salinity, which lasted at least one week. The temporal variations of these environmental factors may particularly affect marine species that live in coastal lagoons (Charpentier et al., 2005; Poizat et al., 2004).
In terms of habitats, can the regression of the Cymodocea nodosa seagrass meadow, replaced by silt bottoms, which occurred in 1994, be related to the late 1993 rainfall event? Cymodocea nodosa is a euryhaline species (Caye and Meinesz, 1986), able to resist low salinity values, so this decline is very unlikely to be related to the salinity drop. This species is also able to grow within a wide range of nutrient concentrations (Perez et al., 1994) and survives under reducing condition of the sediment (Terrados and Ros, 1992; Terrados et al., 1999). Moreover, this species is also resistant to relatively high summer temperatures (Den Hartog, 1970); in any case, between 1990 and 1994, water temperature does not exhibit unusual values (Fig. 2). In contrast $C$. nodosa is sensitive to light availability and siltation (burial) (Marbà and Duarte, 1994) and its decline in the Urbinu lagoon was more marked in deep than in shallow waters. This is consistent with an input of suspended matter of terrestrial origin brought by the freshwater discharge that poured into the lagoon during the flooding of late 1993. Other seagrass species are sensitive to combined sediment load and light availability deterioration influences (e.g. Gacia et al., 2003). However, C. nodosa is a fast-growing species (Caye and Meinesz, 1985) which is known to exhibit year-to-year variations in space occupation (Scarton et al., 1995; Vidondo et al., 1997), so that the 1994 loss followed by recolonization may be explained by the usual range of inter-annual fluctuations.

For the sea urchin population, results obtained reveal wide fluctuations not only in sea urchin numbers but also in their demographic structure. The most striking result is the dramatic $50 \%$ decrease in the number of individuals recorded between 1990 and 1994. Several hypotheses can be proposed to explain this phenomenon. Inter-annual variations in sea urchin numbers at a comparable level to that observed in this study have already been recorded. In the present study, we suggest that the dramatic decrease in the sea urchin population is linked to abiotic factors, notably the high level of freshwater input within the lagoon in late 1993. Several observations allow us to link the decrease in Paracentrotus lividus numbers to the exceptionally low salinity rather than to other causes. (1) Dives regularly carried out from June 1990 to June 1993 on pebble and seagrass area reveal the relative stability of the sea urchin population before the rainfall event. (2) In very early November 1993, a few days after the exceptional rainfall event, large amounts of dead $P$. lividus tests were found underwater and washed up on the beaches of the lagoon, a phenomenon never observed before or since. These dead sea urchins, of all sizes, were observed mainly on pebble bottoms and in lower amounts in seagrass beds. Moreover, in an experimental $P$. lividus rearing pen situated at the edge of the lagoon, $72 \%$ of individuals died during the two weeks that followed the rainfall. (3) The only predators of P. lividus occurring in the lagoon are the fishes Diplodus spp. and Sparus aurata (Linnaeus) which are fished locally. The fishing efforts and fished quantities did not vary noticeably between 1990 and 1994 (Bronzini de Caraffa, personal communication). (4) Bald sea urchin disease (Boudouresque et al., 1980) which decimated Mediterranean populations in the 1980s was never 

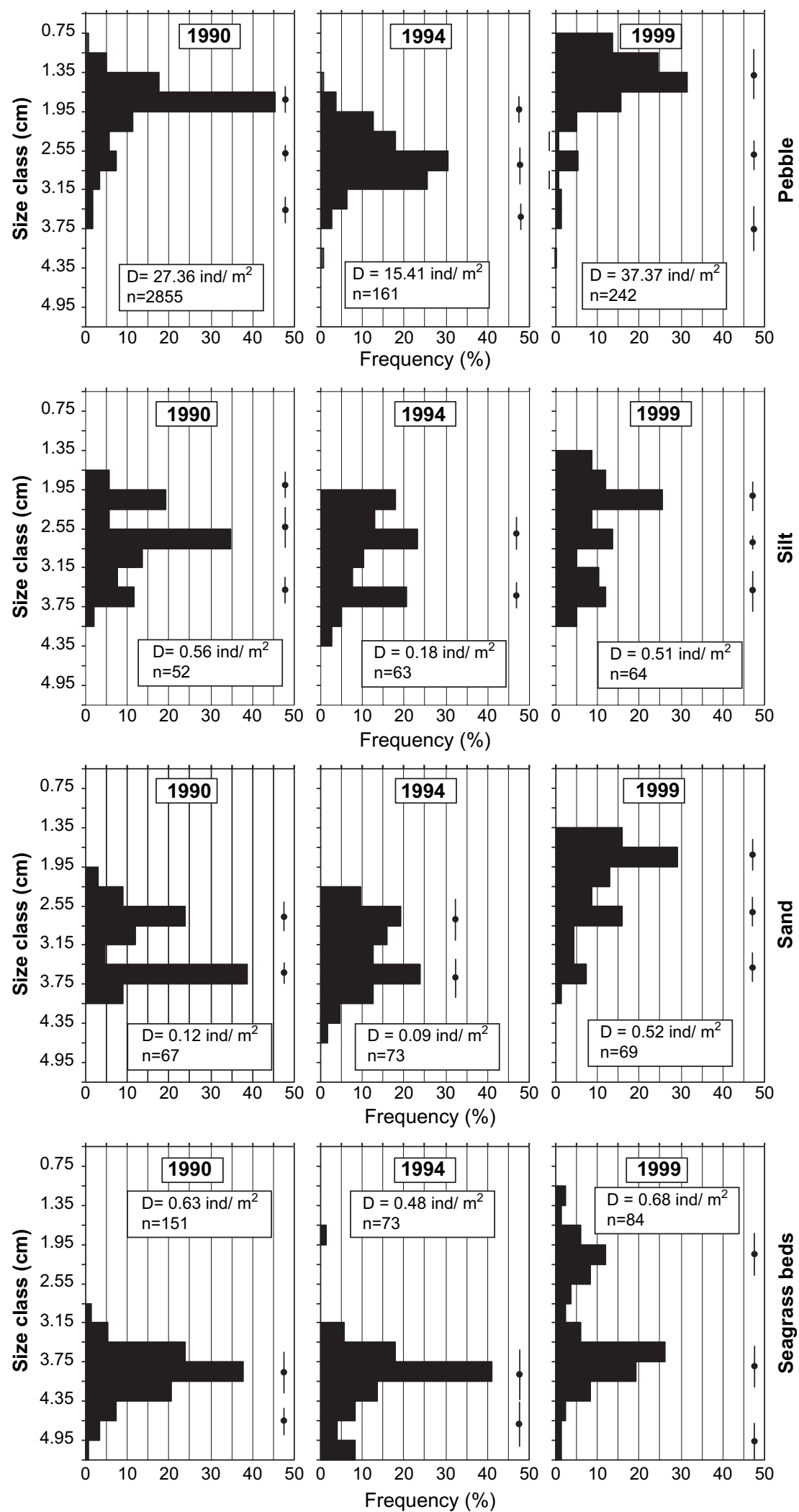

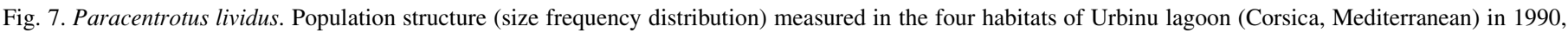

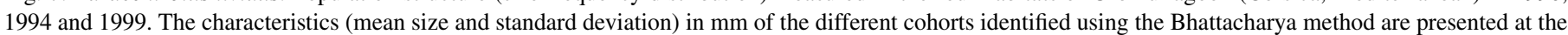
top of each histogram. Density and number of sea urchin measured are also indicated. 
observed during the study period. (5) The temperature was within the tolerance range of the species (Boudouresque and Verlaque, 2001). (6) Finally, Urbinu lagoon is considered as a pollution-free site (Pergent-Martini et al., 2005; Pasqualini et al., 2006). These factors taken together suggest that the saline crisis of late 1993 was responsible for the $50 \%$ decline in the $P$. lividus stock.

Sea urchins have little control of their osmolarity and they have often been considered as strictly marine organisms even if some species can be found in euryhaline environments (Lawrence, 1975; Himmelman et al., 1983). Prolonged exposure to low salinity can be fatal to the sea urchin and massive mortality due to drops in salinity has been observed elsewhere for other urchins (Lawrence, 1975; Andrew, 1991). For Paracentrotus lividus, Le Gall et al. (1989) showed that when decreases in salinity are severe (5-17), mortality is high (up to $100 \%$ ), when salinity is in the order of $15-20$ for long term exposure the mortality rate is less high (Boudouresque and Verlaque, 2001).

Analysis of density and structure of sea urchin populations reveals that the decreases in the number of individuals between 1990 and 1994 were particularly drastic in the pebble and silt habitats. The pebble areas, where the population is the densest, are located near the river mouths which spill into the lagoon and are characterized by shallow depths $(<1 \mathrm{~m})$. Demographic structure in this habitat exhibits a sharp decrease in the number of the smaller individuals. This finding may be explained by the fact that large individuals better withstand osmotic stress than smaller ones (Himmelman et al., 1983). With regard to the silt habitat, which is more distant from freshwater inputs than the pebble bottoms, increased siltation following the exceptional rainfall could constitute the most evident cause of sea urchins decline.

Was the Paracentrotus lividus population able to partially replenish its depleted stock between autumn 1993 and June 1994 ? If this was the case, then the decrease in stock following the 1993 crisis would have been underestimated. In the North-western Mediterranean, $P$. lividus mainly spawns in spring (Lozano et al., 1995). On the basis of the growth rate of this species, recruits proceeding from the 1994 spring spawn could not have reached $8 \mathrm{~mm}$ (minimum size taken into account here) by June 1994 (Turon et al., 1995a; Fernandez and Pergent, 1998). The mean size of 6-month-old $P$. lividus is about $5 \mathrm{~mm}$ (Grosjean et al., 1996). Finally, entry of adult sea urchin from the sea into the lagoon is unlikely as marine bottoms for several hundred meters just beyond the channel are made up of sand. Partial recovery of the stock between the saline crisis and June 1994 is therefore unlikely, suggesting that the observed decrease in stock numbers was not underestimated.

If the results suggest that the rainfall event induced mortality in the sea urchin population, this mortality episode does not appear to have affected the adult sea urchin population. So we cannot rule out the impact of variability of settlement and recruitment on sea urchin stock. Settlement and recruitment of Paracentrotus lividus is variable from one year to another (Turon et al., 1995a; Sala et al., 1998; Hereu et al., 2004) and mortality among recruits can be very high (75-99\%; Sala and Zabala, 1996; López et al., 1998). This variability probably occurs in coastal lagoons. The high density of young urchins in 1999 on pebble habitat is probably due to a high recruitment episode. It seems that sea urchins present mechanisms, such as high population dynamics, high recruitment potential and migration, to maintain the population in this highly variable habitat. With regard to migration, population structure shows the presence of medium size sea urchin $(20-30 \mathrm{~mm})$ in 1999 with high densities $\left(10-35 \mathrm{ind} / \mathrm{m}^{2}\right)$. These sea urchins were localised at the limit between the seagrass and sand habitat and would appear to herald the arrival of a wave of migration. This type of migration might enable the populations present in the seagrass beds to maintain population levels. However, these sea urchins are presenting the form of an aggregation or grazing front which resulted in the overgrazing of seagrasses and the creation of unvegetated patches. This last point confirms the importance of sea urchin grazing in the coastal lagoon ecosystem.

In conclusion, in the Urbinu lagoon, characterized by low freshwater input and permanent communication with the open sea, and therefore by relatively stable salinity, the exceptional rainfall event of 1993 resulted in a dramatic drop in salinity and an increase in turbidity and siltation. These changes are the probable cause of a moderate decrease in the seagrass Cymodocea nodosa surface area, a decrease which, however, could also fall within its usual inter-annual variations. These changes seem to be the main cause, in addition to natural mortality of juveniles, of a more abrupt decline (by 50\%) in the sea urchin Paracentrotus lividus stock. In fact, biotic changes were not as drastic as might have been expected for marine populations faced with a climatic event occurring once every 50 years. The climatic event was apparently within the sea urchin and seagrass resilience range (sensu Connell and Sousa, 1983). Recovery of seagrass meadows and sea urchin stock was completed within a few years (six years or less), suggesting high adjustment stability (sensu Connell and Sousa, 1983) of these biotic compartments. This stability could be attributed to the main biological strategies and characteristics of the two species studied (e.g. fast growth and colonization capacity of C. nodosa, large phenotypical plasticity and strong recruitment events of $P$. lividus) which afford the seagrass bed and sea urchin population the capacity to recover fast and to maintain population levels in this highly variable habitat.

With the increasing intensity of climate change, however, it is feared that such climatic events will become more frequent, in particular in the Mediterranean region (Christensen and Christensen, 2004). Predictions of climate change suggest that there will be an increase in the torrential character of seasonal rains, particularly in France and in the Mediterranean coastal areas (Sánchez et al., 2004). Should these predictions prove correct, increased rainfall and freshwater runoff into coastal lagoons would generate substantial fluctuations in salinity that may, if too extreme, affect the resilience capacity of sea urchin populations and bring about their decline or even disappearance in these lagoonal ecosystems. 


\section{Acknowledgements}

The authors wish to thank L. Bronzini de Caraffa, who allowed us to work in Urbinu lagoon and who provided sea transportation. We are grateful to Prof. G. Pergent for providing computer image processing equipment and to Dr. J. Le Campion, Station Marine d'Endoume, for his help with the statistical aspects of this study. We are grateful to Prof. D. Viale, University of Corsica, for providing laboratory facilities. We thank all the divers who took part in the sampling campaign in particular Dr. F. Morandini, Dr. O. Dumay and R. Gazzola and people working in the lagoon (fishermen, fish farmers), in particular Y. Leberigaud for information on environmental data. Finally, we would like to thank Michael Paul for correcting and improving the English and the two anonymous referees for their comments and valuable criticism.

\section{References}

Andrew, N.L., 1991. Changes in subtidal habitat following mass mortality of sea urchins in Botany Bay, New South Wales. Australian Journal of Ecology $16,353-362$.

Bak, H.P., Nojima, D., 1980. Immigration of a tropical sea urchin, Astropyga radiata (Leske), in a temperate eelgrass, Zostera marina L., patch: it's feeding habit and grazing effect on the patch. Publication of Amakusa Marine Biology Laboratory 5, 153-169.

Bhattacharya, C.G., 1967. A simple method of resolution of a distribution into Gaussian components. Biometrics 123, 11-25.

Boudouresque, C.F., Nedelec, H., Shepherd, S.A., 1980. The decline of the sea urchin Paracentrotus lividus in the bay of Port-Cros (Var, France). Travaux Scientifique du Parc national de Port-Cros 6, 243-251.

Boudouresque, C.F., Verlaque, M., 2001. Ecology of Paracentrotus lividus. In: Lawrence, J.M. (Ed.), Edible Sea Urchins: Biology and Ecology. Developments in Aquaculture and Fisheries Science. Elsevier, Amsterdam, pp. 177-216.

Caye, G., Meinesz, A., 1985. Observations on the vegetative development, flowering and seeding of Cymodocea nodosa (Ucria) Ascherson on the Mediterranean coasts of France. Aquatic Botany 22 (3-4), 277-289.

Caye, G., Meinesz, A., 1986. Experimental study of seed germination in the seagrass Cymodocea nodosa. Aquatic Botany 26, 79-87.

Christensen, O.B., Christensen, J.H., 2004. Intensification of extreme European summer precipitation in warmer climate. Global Planet Change 44, 107-117.

Charpentier, A., Grillas, P., Lescuyer, F., Coulet, E., Auby, I., 2005. Spatiotemporal dynamics of a Zostera noltii dominated community over a period of fluctuating salinity in a shallow lagoon, Southern France. Estuarine, Coastal and Shelf Science 64 (2-3), 307-315.

Cebrian, J., Duarte, C.M., 1998. Patterns in leaf herbivory on seagrasses Aquatic Botany $60,67-82$.

Cebrian, J., Duarte, C.M., Marba, N., 1996. Herbivory on the seagrass Cymodocea nodosa (Ucria) Ascherson in contrasting Spanish Mediterranean habitats. Journal of Experimental Marine Biology and Ecology 204, 103-111.

Connell, J.H., Sousa, W.P., 1983. On the evidence needed to judge ecological stability or persistence. The American Naturalist 121, 789-824.

Den Hartog, C., 1970. The seagrasses of the world. Verhandelingen der Koninklijke Nederlandse Akademie van Wetenschappen, Afdeeling Letterkunde, 275 pp. (North-Holland Publ., Amsterdam).

Efron, B., 1979. Bootstrap methods: another look at the jackknife. Annals of Statistics 7, 1-26.

Efron, B., Tibshinari, R., 1993. An Introduction to the Bootstrap. Chapman and Hall, London, 436 pp.

Fenaux, L., Etienne, M., Quelart, G., 1987. Suivi écologique d'un peuplement de Paracentrotus lividus (Lamarck) dans la baie de Villefranche-sur-mer (France). In: Boudouresque, C.F. (Ed.), Colloque international sur Paracentrotus lividus et les oursins comestibles. GIS Posidonie, Marseille, pp. 187-197.
Fernandez, C., Caltagirone, A., 1990. Données préliminaires sur la populations de Paracentrotus lividus de l'étang d'Urbinu (Corse). Rapport de la Commission Internationale d'Exploration de la Mer Méditerranée 32 (1), 37.

Fernandez, C., Pergent, G., 1998. Effect of different formulated diets and rearing conditions on growth parameters in the sea urchin Paracentrotus lividus. Journal of Shellfish Research 17, 1571-1581.

Fernandez, C., Caltagirone, A., Johnson, M., 2001. Demographic structure suggests migration of the sea urchin Paracentrotus lividus (Echinodermata: Echinoidea) in a coastal lagoon. Journal of the Marine Biological Association of the United Kingdom 81, 361-362.

Fernandez, C., Boudouresque, C.F., 1997. Phenotypic plasticity of Paracentrotus lividus (Echinodermata: Echinoidea) in a lagoonal environment. Marine Ecology Progress Series 152, 145-154.

Frontier, S., 1983. Stratégie d'échantillonnage. Masson and PUL, Paris, 494 pp.

Gacia, E., Duarte, C.M., Marbà, N., Terrados, J., Kennedy, H., Fortes, M.D., Tri, N.H., 2003. Sediment deposition and production in SE-Asia seagrass meadows. Estuarine, Coastal and Shelf Science 56, 909-919.

Grosjean, P., Spirlet, C., Jangoux, M., 1996. Experimental study of growth in the echinoid Paracentrotus lividus (Lamarck, 1816) (Echinodermata). Journal of Experimental Marine Biology and Ecology 201, 173-184.

Hereu, B., Zabala, M., Linares, C., Sala, E., 2004. Temporal and spatial variability in settlement of the sea urchin Paracentrotus lividus in the NW Mediterranean. Marine Biology 144, 1011-1018.

Himmelman, J.H., Lavergne, Y., Axelsen, F., Cardinal, A., Bourget, E., 1983. Sea urchins in the St. Lawrence estuary: their abundance, size structure, and suitability for commercial exploitation. Canadian Journal of Fisheries and Aquatic Science 40, 474-486.

Heck, K.L., Valentine, J.F., 1995. Sea urchin herbivory: evidence for longlasting effects in subtropical seagrass meadows. Journal of Experimental Marine Biology and Ecology 189, 205-217.

IPCC, 1995. Climate Change 1995. WMO/UNEP Intergovernmental Panel on Climate Change, Second Assessment Report. Cambridge University Press, 64 pp. http://www.ipcc.ch/pub/sa(E).pdf.

Kjerfve, B., 1994. Coastal Lagoon Processes. Elsevier Oceanography Series 60. Elsevier, Amsterdam, 577 pp.

Knuth, D.E., 1997. Seminumerical Algorithms. The Art of Computer Programming, third ed., vol. 2. Addison-Wesley, New York, xiv +762 pp.

Lardicci, C., Rossi, F., Castelli, A., 1997. Analysis of macrozoobenthic community structure after severe dystrophic crises in a Mediterranean coastal lagoon. Marine Pollution Bulletin 3, 536-547.

Lawrence, J.M., 1975. The effect of temperature-salinity combinations on the functional well-being of adult Lytechinus variegatus (Lamarck) (Echinodermata: Echinoidea). Journal of Experimental Marine Biology and Ecology 18, 271-275.

Lawrence, J.M., Sammarco, P.W., 1982. Effect of feeding on the environment: Echinoidea. In: Jangoux, M., Lawrence, J.M. (Eds.), Echinoderm Nutrition. Balkema, Rotterdam, pp. 499-519.

Le Gall, P., Bucaille, D., Dutot, P., 1989. Résistance aux variations de salinité chez Paracentrotus et Psammechinus. Vie Marine HS 10, 83-84.

Legendre, P., Legendre, L., 1998. Numerical Ecology. Elsevier, Amsterdam, 853 pp.

Levin, L.A., Boesch, D.F., Covich, A., Dahm, C., Erseus, C., Ewel, K.C., Kneib, R.T., Moldenke, A., Palmer, M.A., Snelgrove, P., Strayer, D., Weslawski, J.M., 2001. The function of marine critical transition zones and the importance of sediment biodiversity. Ecosystems 4, 430-451.

López, S., Turon, X., Montero, E., Palacín, C., Duarte, C.M., Tarjuelo, I., 1998. Larval abundance, recruitment and early mortality in Paracentrotus lividus (Echinoidea). Interannual variability and plankton-benthos coupling. Marine Ecology Progress Series 172, 239-251.

Lozano, J., Galera, J., López, S., Turon, X., Palacín, C., Morera, G., 1995. Biological cycles and recruitment of Paracentrotus lividus (Echinodermata: Echinoidea) in two contrasting habitats. Marine Ecology Progress Series 122, 179-191.

Maggiore, F., Berthon, J.F., Boudouresque, C.F., Lawrence, J.M., 1987. Données préliminaires sur les relations entre Paracentrotus lividus, Arbacia lixula et le phytobenthos dans la baie de Port-Cros (Var, France, Méditerranée). In: Boudouresque, C.F. (Ed.), Colloque international sur Paracentrotus lividus et les oursins comestibles. GIS Posidonie, Marseille, pp. $65-82$. 
Manly, B.F.J., 1998. Randomization, Bootstrap and Monte Carlo Methods in Biology. Chapman and Hall, London, 399 pp.

Maciá, S., Lirman, D., 1999. Destruction of Florida Bay seagrass by grazing front of sea urchins. Bulletin of Marine Sciences 65, 593-601.

Marbà, N., Duarte, C.M., 1994. Growth response of the seagrass Cymodocea nodosa to experimental burial and erosion. Marine Ecology Progress Series $107,307-311$.

Palacin, C., Giribet, G., Carner, S., Dantart, L., Turon, X., 1998. Low densities of sea urchins influence the structure of algal assemblages in the western Mediterranean. Journal of Sea Research 39, 281-290.

Pasqualini, V., Pergent-Martini, C., Fernandez, C., Pergent, G., 1997. The use of airborne remote sensing for benthic cartography: advantages and reliability. International Journal of Remote Sensing 18, 1167-1177.

Pasqualini, V., Pergent-Martini, C., Fernandez, C., Ferrat, L., Tomaszewski, J.E., Pergent, G., 2006. Vegetation monitoring in two Corsican coastal lagoons (Western Mediterranean sea). Aquatic Conservation 16, 43-60.

Perez, M., Duarte, C.M., Romero, J., Sand-Jensen, K., Alcoverro, T., 1994. Growth plasticity in Cymodocea nodosa stands: the importance of nutrient supply. Aquatic Botany 47, 249-264.

Pergent-Martini, C., Pasqualini, V., Ferrat, L., Pergent, G., Fernandez, C., 2005. Seasonal dynamics of Zostera noltii Hornem. in two Mediterranean lagoons. Hydrobiologia 543 (1), 233-243.

Poizat, G., Rosecchi, E., Chauvelon, P., Contournet, P., Crivelli, A.J., 2004. Long-term fish and macro-crustacean community variation in a Mediterranean lagoon. Estuarine, Coastal and Shelf Science 59 (4), 615-624.

Sala, E., Zabala, M., 1996. Fish predation and the structure of the sea urchin Paracentrotus lividus populations in the NW Mediterranean. Marine Ecology Progress Series 140, 71-81.

Sala, E., Boudouresque, C.F., Harmelin-Vivien, M., 1998. Fishing, trophic cascades, and the structure of algal assemblages: evaluation of an old but untested paradigm. Oikos 82, 425-439.

Sánchez, E., Gallardo, C., Gaertner, M.A., Arribas, A., Castro, M., 2004. Future climate extreme events in the Mediterranean simulated by a regional climate model: a first approach. Global Planet Change 44, 163-180.
Scarton, F., Curiel, D., Rismondo, A., 1995. Aspetti della dinamica temporale di praterie a fanerogame marine in laguna de Venezia. Lavori Societa Veneziana de scienze Naturali 20, 95-102.

Solidoro, C., Melaku Canu, D., Rossi, R., 2003. Ecological and economic considerations on fishing and rearing of Tapes phillipinarum in the lagoon of Venice. Ecological Modelling 170, 303-318.

Terrados, J., Ros, J.D., 1992. Growth and primary production of Cymodocea nodosa (Ucria) Ascherson in a Mediterranean coastal lagoon: the Mar Menor (SE Spain). Aquatic Botany 43, 63-74.

Terrados, J., Duarte, C.M., Kamp-Nielsen, L., Agawin, N.S.R., Gacia, E., Lacamp, D., Fortes, M.D., Borum, J., Lubanski, M., Greve, T., 1999. Are seagrass growth and survival constrained by the reducing conditions of sediment? Aquatic Botany 65, 175-197.

Traer, K., 1980. The consumption of Posidonia oceanica Delile by echinoids at the isle of Ischia. In: Jangoux, M. (Ed.), Echinoderm: Present and Past. Balkema, A.A. Publ., Rotterdam, pp. 241-244.

Turon, X., Giribet, G., López, S., Palacín, C., 1995a. Growth and population structure of Paracentrotus lividus (Echinodermata: Echinoidea) in two contrasting habitats. Marine Ecology Progress Series 122, 193-204.

Turon, X., Palacín, C., Ballesteros, M., Dantart, L., 1995b. A case study of stock evaluation on littoral hard substrata: echinoid population on the north-east coast of Spain. In: Eleftheriou, A. (Ed.), Biology and Ecology of Shallow Waters. 28 EMBS Symposium. Olsen and Olsen Publ., Fredensborg, pp. 333-340.

Verlaque, M., 1987. Relations entre Paracentrotus lividus (Lmk.) et le phytobenthos de Méditerranée occidentale. In: Boudouresque, C.F. (Ed.), Colloque international sur Paracentrotus lividus et les oursins comestibles. GIS Posidonie Publ., Marseille, pp. 5-36.

Vidondo, B., Middleboe, A.L., Stefansen, K., Lützen, T., Nielsen, S.L., Duarte, C.M., 1997. Dynamics of a patchy seagrass (Cymodocea nodosa) landscape. Size and age distributions, growth and demography of seagrass patches. Marine Ecology Progress Series 158, 131-138.

Zar, J.H., 1999. Biostatistical Analysis, fourth ed. Prentice Hall International, Englewood Cliffs, xii +663 pp. +212 pp. +11 pp. +20 pp. +23 pp. 